\title{
PEMANFAATAN PUPUK ORGANIK DARI LIMBAH CANGKANG TELUR UNTUK LAHAN PERTANIAN MELALUI PENGABDIAN KEPADA MASYARAKAT
}

\author{
Sarah Dampang1), Vita Efelina²), Riza Ibnu Adam ${ }^{3)}$, Reni Rahmadewi ${ }^{4)}$, Endah Purwanti( ${ }^{5)}$ \\ 1)Program Studi S-1 Teknik Kimia, Fakultas Teknik, Universitas Singaperbangsa Karawang, Kabupaten Karawang, \\ Provinsi Jawa Barat, Indonesia \\ 2)Program Studi S-1 Teknik Lingkungan, Fakultas Teknik, Universitas Singaperbangsa Karawang, Kabupaten \\ Karawang, Provinsi Jawa Barat, Indonesia \\ 3)Program Studi S-1 Teknik Informatika, Fakultas IImu Komputer, Universitas Singaperbangsa Karawang, Kabupaten \\ Karawang, Provinsi Jawa Barat, Indonesia \\ 4)Program Studi S-1 Teknik Elektro, Fakultas IImu Komputer, Universitas Singaperbangsa Karawang, Kabupaten \\ Karawang, Provinsi Jawa Barat, Indonesia \\ ${ }^{5}$ Program Studi S-1 Teknik Industri, Fakultas IImu Komputer, Universitas Singaperbangsa Karawang, Kabupaten \\ Karawang, Provinsi Jawa Barat, Indonesia
}

Corresponding author : Sarah Dampang

E-mail : sarah.dampang@staff.unsika.ac.id

Diterima 27 November 2021, Disetujui 02 Desember 2021

\begin{abstract}
ABSTRAK
Penanggulangan limbah yang dimanfaatkan dari segi pengetahuan masyarakat dapat dikatakan masih minim, terutama masyarakat desa. Seperti yang diketahui, ketika limbah yang dinyatakan sudah tidak terpakai namun ketika di daur ulang dapat mengurangi jumlah sampah secara signifikan. Desa Kutamekar yang terletak di Kecamatan Ciampel - Kabupaten Karawang terbilang cukup banyak menjadi produsen dan konsumen telur. Sehingga hal ini cepat lambat akan menumpuknya limbah cangkang telur di lingkungan sekitar permukiman. Maka melalui Pengabdian Kepada Masyarakat ini, bertujuan untuk melakukan sosialisasi, edukasi dan implementasi dalam pemanfaatan pupuk organik dari limbah cangkang telur untuk lahan pertanian. Materi Pengabdian Kepada Masyarakat berupa membandingkan hasil dari $\mathrm{CaCO} 3$ dari Cangkang Telur dan $\mathrm{CaCO} 3$ Komersil, didapatkan hasilnya yang tidak terlalu jauh. Namun berdasarkan hasil uji laboratorium yang dilakukan terdapat banyak di Cangkang Telur. Maka sebagai bentuk implementasi pemberian pupuk dilakukan terhadap tanaman pakcoy. Dari hal ini dilakukan pengamatan setiap minggu sekali yang dilakukan di hari minggu selama 1 bulan. Sebagai kesimpulan dilakukan penyebaran kuesioner terhadap masyarakat guna mengetahaui seberapa jauh materi yang telah dilaksanakan.
\end{abstract}

Kata kunci: cangkang telur; pupuk organik; $\mathrm{CaCO} 3$.

\begin{abstract}
Waste management that is utilized in terms of community knowledge can be said to be still minimal, especially the village community. As is known, when the waste is declared unused but when recycled can reduce the amount of waste significantly. Kutamekar Village located in Ciampel District - Karawang Regency is quite a lot to be a producer and consumer of eggs. So this will quickly accumulate eggshell waste in the environment around the settlement. So through this Community Service, it aims to socialize, educate and implement in the utilization of organic fertilizers from eggshell waste for agricultural land. Community Service Material in the form of comparing the results of $\mathrm{CaCO} 3$ from EggShells and Commercial $\mathrm{CaCO} 3$, obtained results that are not too far away. But based on the results of laboratory tests conducted there are many in the eggshell. So as a form of implementation of fertilizer delivery is carried out on pakcoy plants. From this is done observations every week that is done on sundays for 1 months. In conclusion, the dissemination of questionnaires to the community to determine how far the material has been implemented.
\end{abstract}

Keywords: eggshell; organic fertilizers; CaCO3.

\section{PENDAHULUAN}

Pada masa digitalisasi saat ini, seluruh masyarakat diharuskan guna menghasilkan luaran produk yang terdapat nilai tambah. Selain itu dengan memerhatikan dari segi kualitas yang terbaik guna dapat bersaing dengan produk import di pasaran. Masyarakat dituntut untuk menghasilkan kreasi atau inovasi terbarukan agar produk dapat diminati oleh konsumen, baik dalam ataupun luar negeri. Sebagaian hal yang dapat membuat produk menjadi nilai tambah dan dengan investasi 
sedikit, yaitu dengan cara menanggulangi limbah yang dirasa tidak terpakai di lingkungan sekitar. Melalui pembuatan produk yang didapatkan dari pengolahan limbah: (1) Dapat meminimalisir pencemaran lingkungan, (2) Dapat menghasilkan produk yang bernilai tambah, dan (3) Dapat menjaga lingkungan dari limbah yang berserakan (Mushawwir \& Latipudin, 2013).

Maka dari itu sebagai hal yang dapat dijadikan dan bernilai tambah adalah cangkang telur. Cangkang telur adalah limbah daur ulang yang mudah ditemui dalam sehari-hari. Hasil produksi cangkang telur ayam di Indonesia per tahunya dapat mencapai $-/+150.000$ ton (Badan Pusat Statistik (BPS), 2016). Menurut G. D. Butcher dan R. Miles (2012) mengatakan bahwa kandungan cangkang telur terdapat: (1) 97\% Kalsium Bikarbonat, (2) Fosfor, (3) Magnesium, (4) Natrium, (5) Kalium, (6) Seng, (7) Mangan, (8) Besi, dan (9) Tembaga. Cangkang telur mengandung $-/+95,1 \%$ merupakan garam-garam organik, 3,3\% bahan organik (terutama protein), dan 1,6\% air (Ernawati, et al., 2019). Indikator utama dari garam anorganik dari cangkang telur ayam didominasi dari kalsium bikarbonat (CaCO3). Selain itu dengan kandungan lainnya berupa kalsium fosfat dan magnesium kabornat yang masing-masing mengandung komposisi sekitar $0,7 \%$ (Mahreni, et al., 2012). Dari tingginya kadar garam yang diselingi dengan adanya senyawa organik dari telur telur ayam dapat berpotensi mengotori lingkungan. Hal ini diakibatkan oleh aktivitas mikroba yang berada di dalam cangkang telur. Kandungan kalsium di cangkang telur dapat dikatakan cukup besar dan dapat dijadikan sumber nutrisi untuk tumbuhan. Kalsium adalah bagian zat yang memiliki peran penting untuk pembentukan struktur tubuh, tulang, dan gigi untuk manusia dan hewan serta dinding sel pada tumbuhan (Noviyanti, et al., 2017). Melalui peran kalsium lain terkhusus pada tumbuhan antara lain: (1) Dapat menebalkan dinding sel, (2) Dapat meningkatkan pemanjangan sel akar, (3) Kofaktor proses Enzimatis, dan Hormonal, seta (4) Dijadikan pelindung dari cekaman panas, hama dan penyakit (Nurjayanti, et al., 2012).

Pada tumbuhan memiliki ketersediaan nutrisi kalsium yang didapatkan melalui media tanaman dan pemberian pupuknya. Kalsium pada pupuk adalah senyawa makro selain nitrogen, fosfor, dan kalium. Hal ini berfungsi sebagai pendorong dalam pembentukan dan pertumbuhan akar yang lebih awal, memperbaiki kekuatan tanaman, dan meningkatkan $\mathrm{pH}$ tanah. Tumbuhan membutuhkan kalsium sekitar 0,1\% - 5\% (1000 ppm - 50.000 ppm) dihasilkan oleh media tanam. Namun jika tuumbuhan kekurangan kalsium, maka metabolisme tumbuhan dapat terjadinya gangguan yang tidak normal. Gangguan ini biasanya akan muncul yang diakibatkan oleh pengaturan kalsium yang lambat dari jaringan yang berlebih. Fenomena ini dapat menjangkit ke seluruh bagian jaringan tumbuhan dan dapat mematikan tumbuhan secara perlahan (Nurlaela, et al., 2014). Melalui ketersediaan tumbuhan nutrisi kalsium didapatkan dari media tanam dan pemberian pupuk. Pupuk kalsium didapatkan dari pupuk kapur atau dari pupuk buatan. Namun ternyata pupuk tersebut dinilai kurang ekonomis karena akan menambah biaya produksi. Sedangkan dalam penggunaan pupuk organik belum tentu dapat memenuhi kebutuhan kalsium tanaman. Hal ini dikarenakan zat hara pada pupuk masing-masingnya beragam dan tidak terspesifikasi. Oleh sebab itu, dibutuhkan pupuk kalsium alami yang dapat mengubah penggunaan pupuk kalsium buatan tersebut. Maka melalui Pengabdian Kepada Masyarakat ini, bertujuan untuk melakukan sosialisasi, edukasi dan implementasi dalam pemanfaatan pupuk organik dari limbah cangkang telur untuk lahan pertanian.

\section{METODE \\ Kondisi Eksisting}

Pemanfaatan limbah cangkang telur sebagai pupuk organik tumbuhan dilakukan di Desa Kutamekar, Kecamatan Ciampel, Kabupaten Karawang. Dapat diketahui masyarakat masih minim pengetahuan terhadap penanggulangan limbah, yaitu cangkang telur yang dapat dimanfaatkan. Maka dilakukannya pengabdian kepada masyarakt ini mengingat kondisi lingkungan sekitar desa yang sudah cukup banyak limbah. Sehingga dirasa perlu untuk dilakukannya pengabdian kepada masyarakat. Metode pengabdian kepada masyarakat ini terdapat beberapa tahapan: (1) Sosialiasi bertujuan untuk menyampaikan akan kepedulian lingkungan sekitar terhadap limbah yang ada dan memanfaatkan limbah menjadi hal yang bermanfaat, (2) Edukasi bertujuan untuk memberikan pelatihan secara langsung mengenai penanggulangan limbah, yaitu cangkang telur yang dapat di daur ulang menjadi pupuk organik, dan (3) Implementasi bertujuan untuk mengetahui hasil dari Sosialisasi dan Edukasi secara praktiknya, sehingga masyarakat dapat melakukannya nanti secara mandiri..

\section{Kegiatan Pengabdian Kepada Masyarakat}

Pengabdian kepada masyarakat ini dilakukan dengan teknik analisis focus and 
group discussion (FGD) dengan beberapa masyarakat desa, terutama kelompok petani lokal. Berikut alat dan bahan yang diperlukna: (1) Alat penumbuk/palu, (2) Tampah, (3) Wadah/ember, (4) Toples/kaleng, (5) Cangkang telur, (6) Air, dan (7) Tumbuhan pakcoy. Selain itu berikut ini adalah cara pembuatannya:

a. Kumpulkan terlebih dahulu cangkang telur, kemudian cuci dengan air bersih dengan menggunakan wadah/ember.

b. Keringkan cangkang telur yang telah bersih diletakkan di atas tampah.

c. Tumbuk cangkang telur yang telah mengering sampai menjadi bubuk dengan alat penumbuk/palu.

d. Kumpulkan bubuk/serbuk cangkang telur ke toples/kaleng untuk disimpan.

e. Serbuk/bubuk cangkang telur dapat digunakan sebagai pupuk organik untu lahan pertanian/perkebunan.

Maka setelah itu dilakukan pengecekan pengembangan terhadap tumbuhan pakcoy yang tidak diberi dan diberi pupuk organik dari cangkang telur. Pengecekan dilakukan setiap seminggu sekali, di setiap hari minggu selama 1 bulan.

\section{HASIL DAN PEMBAHASAN \\ Kandungan Cangkang Telur Berdasarkan Uji Laboratorium}

Cangkang telur bagian dari limbah rumah tangga, menurut Ayu Intan Safitri, Nurul Muslihah dan Sri Winarsih (2014) mengandung 95\% kalsium karbonat, 3\% fosfor, dan 3\% magnesium, natrium, kalium, seng, mangan, besi, dan tembaga. Maka guna mengetahui kandungan cangkang telur untuk pengabdian kepada masyarakat ini dilakukan pengujian di laboratorium. Berikut ini adalah Hasil Pengujian Unsur $\mathrm{CaCO} 3$ Komersil dengan Metode Uji : ED-XRF Kualitatif (Fundamental Parameter/Standardless) pada Tabel 1.

Tabel 1. Hasil Pengujian Unsur $\mathrm{CaCO} 3$ Komersil

\begin{tabular}{ccc}
\hline Komponen & Hasil & Satuan \\
\hline $\mathrm{S}$ & 0,127 & Mass $\%$ \\
$\mathrm{Ca}$ & 99,329 & $\mathrm{Mass} \%$ \\
$\mathrm{Fe}$ & 0,197 & $\mathrm{Mass} \%$ \\
$\mathrm{Ni}$ & 0,181 & $\mathrm{Mass} \%$ \\
$\mathrm{Cu}$ & 691 & $\mathrm{Mg} / \mathrm{Kg}$ \\
$\mathrm{Zn}$ & 391,9 & $\mathrm{Mg} / \mathrm{Kg}$ \\
$\mathrm{Sr}$ & 578 & $\mathrm{Mg} / \mathrm{Kg}$ \\
\hline
\end{tabular}

Selain itu berikut ini adalah Hasil Pengujian Unsur CaCO3 Cangkang Telur dengan Metode Uji : ED-XRF Kualitatif
(Fundamental Parameter/Standardless) pada Tabel 2.

Tabel 2. Hasil Pengujian Unsur $\mathrm{CaCO} 3$ Cangkang Telur

\begin{tabular}{ccc}
\hline Komponen & Hasil & Satuan \\
\hline $\mathrm{S}$ & 0,956 & Mass $\%$ \\
$\mathrm{Ca}$ & 98,252 & Mass $\%$ \\
$\mathrm{Fe}$ & 0,288 & Mass $\%$ \\
$\mathrm{Ni}$ & 0,198 & $\mathrm{Mass} \%$ \\
$\mathrm{Cu}$ & 757 & $\mathrm{Mg} / \mathrm{Kg}$ \\
$\mathrm{Zn}$ & 472 & $\mathrm{Mg} / \mathrm{Kg}$ \\
$\mathrm{Sr}$ & 0,183 & $\mathrm{Mass} \%$ \\
\hline
\end{tabular}

\section{Hasil Pengujian terhadap Tumbuhan Pakcoy}

Unsur nutrisi yang terdapat pada tumbuhan pakcoy salah satunya adalah kalsium. Hasil pemberian pupuk cangkang telur dengan indikator tinggi tanaman pakcoy dapat dilihat pada Tabel 5. Tinggi tanaman pakcoy diukur dengan interval 7 hari dari 0 HST hingga
28 HST. Berdasarkan Tabel 3. maka rata-rata tinggi tumbuhan pakcoy tertinggi adalah pada perlakuan p1u1 (pemberian pupuk cangkang telur dengan dosis 5 gram). Rata-rata tinggi tumbuhan pakcoy terendah terdapat pada tumbuhan pakcoy yang di beri perlakuan p3u3 (pemberian pupuk cangkang telur dengan dosis 15 gram). 
Tabel 3. Hasil Pengujian terhadap Tumbuhan Pakcoy (Rata-Rata Tinggi Tumbuhan)

\begin{tabular}{cc}
\hline Perlakuan & Rata-Rata Tinggi Tumbuhan \\
\hline p0u1 & 7,3 \\
p0u2 & 5,9 \\
p0u3 & 4,3 \\
p0u4 & 4,3 \\
p1u1 & $9,1^{*}$ \\
p1u2 & 8,0 \\
p1u3 & 7,9 \\
p1u4 & 4,7 \\
p2u1 & 7,4 \\
p2u2 & 4,3 \\
p2u3 & 5,0 \\
p2u4 & 5,7 \\
p3u1 & 7,3 \\
p3u2 & 8,7 \\
p3u3 & $4,2^{* *}$ \\
p3u4 & 6,1 \\
\hline
\end{tabular}

Keterangan : : ${ }^{*}$ rata-rata tertinggi

*rata-rata terendah

Sedangkan berikut ini adalah seberapa besar pengaruhnya dari pemberian pupuk organik, yaitu cangkang telur terhadap tumbuhan pakcoy. Berikut hasilnya pada Tabel
4. Hasil Pengolahan Data Menggunakan Rancangan Acak Kelompok (Faktor Tunggal)

Tabel 4. Hasil Pengolahan Data Menggunakan Rancangan Acak Kelompok (Faktor Tunggal) Tests of Between-Subjects Effects

\begin{tabular}{c|ccccc}
\hline \multicolumn{7}{c}{ Dependent Variable: Tinggi_Tumbuhan } \\
\hline Source & $\begin{array}{c}\text { Type III Sum of } \\
\text { Squares }\end{array}$ & df & $\begin{array}{c}\text { Mean } \\
\text { Square }\end{array}$ & F & Sig. \\
\hline Corrected Model & 28,045 & 6 & 4,674 & 2,729 &, 085 \\
Intercept & 627,503 & 1 & 627,503 & 366,425 &, 000 \\
ulangan & 17,853 & 3 & 5,951 & 3,475 &, 064 \\
perlakuan & 10,193 & 3 & 3,398 & 1,984 &, 187 \\
Error & 15,413 & 9 & 1,713 & & \\
Total & 670,960 & 16 & & & \\
Corrected Total & 43,458 & 15 & & & \\
\hline
\end{tabular}

Melalui Tabel 4. bahwa terdapat pengaruh nyata dari pemberian pupuk cangkang telur terhadap pertumbuhan hasil tumbuhan pakcoy.

Tabel 5. Hasil Pengolahan Data Menggunakan Uji Lanjut Duncan

\begin{tabular}{|c|c|c|c|}
\hline & Perlakuan & $\mathrm{N}$ & $\begin{array}{c}\text { Subset } \\
1\end{array}$ \\
\hline \multirow{5}{*}{$\begin{array}{c}\text { Duncana, } \\
\text { b }\end{array}$} & p0 & 4 & 5,4500 \\
\hline & p2 & 4 & 5,6000 \\
\hline & p3 & 4 & 6,5750 \\
\hline & $\mathrm{p} 1$ & 4 & 7,4250 \\
\hline & Sig. & & ,077 \\
\hline
\end{tabular}

Begitu juga dengan Tabel 5. bahwa pemberian pupuk cangkang telur dengan dosis sebanyak 5 gram memberikan pengaruh tertinggi terhadap tinggi tumbuhan, dengan indeks sebesar 7,425 berbeda nyata dengan perlakuan lainnya.

\section{Dokumentasi Kegiatan Pengabdian Kepada Masyarakat \\ Berikut beberapa bentuk dokumentasi} kegiatan pengabdian kepada masyarakat yang telah dilaksanakan, seperti pada Gambar 1. di bawah ini. 

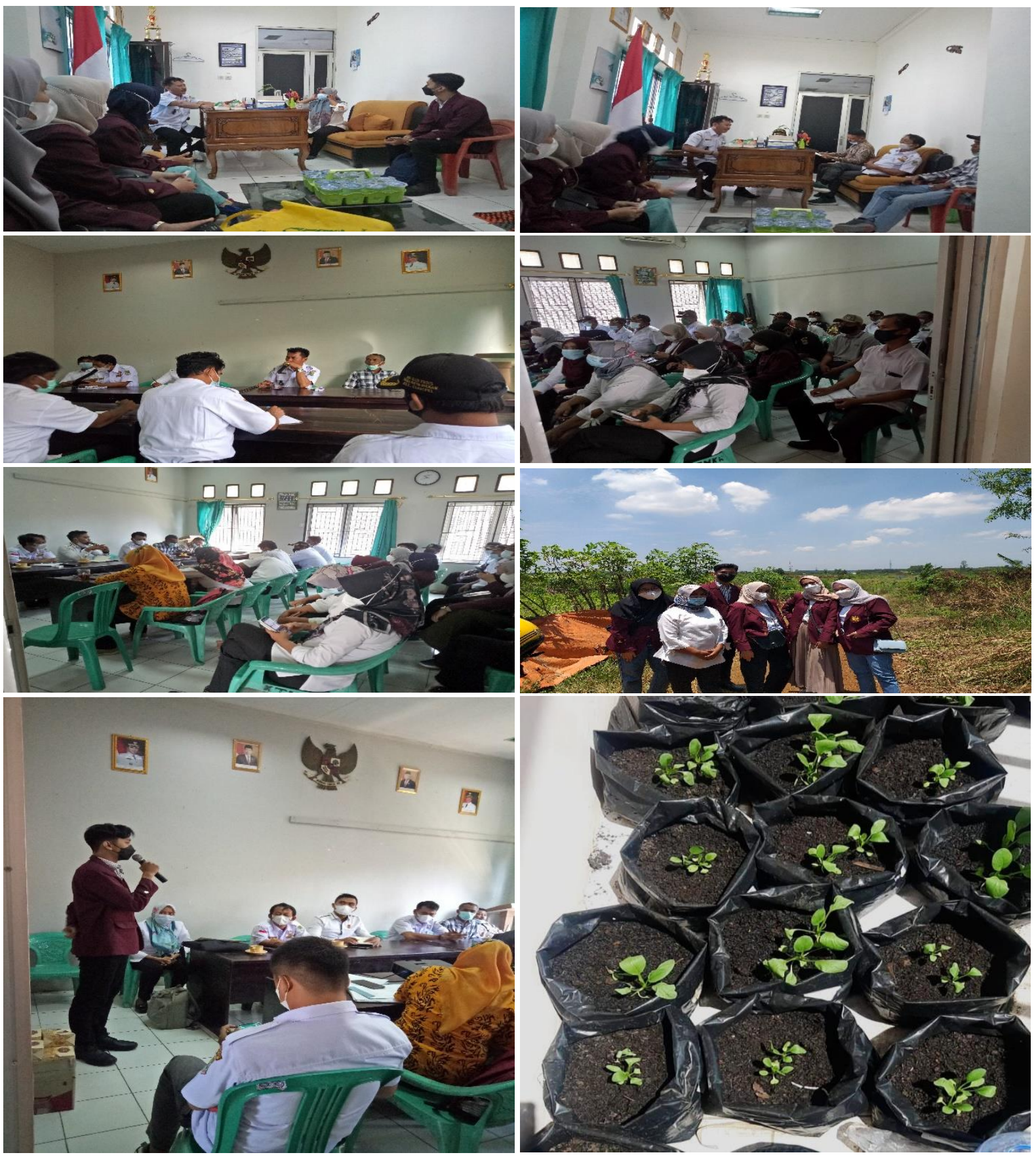

Gambar 1. Dokumentasi Kegiatan Pengabdian Kepada Masyarakat

\section{SIMPULAN DAN SARAN}

Cangkang telur bagian dari limbah rumah tangga yang di dalamnya mengandung unsur: (1) $95 \%$ kalsium karbonat, (2) $3 \%$ fosfor, dan (3) $3 \%$ magnesium yang masingmasingnya terdapat natrium, kalium, seng, mangan, besi, dan tembaga. Hal ini sebagai faktor untuk menyuburkan tanaman. Sehingga dapat dimanfaatkan sebagai salah satu pupuk organik. Melalui hasil pengabdian kepada masyarakat mengenai pemberian pupuk organik, yaitu cangkang telur ternyata sangat berpengaruh dalam meningkatkan tinggi tumbuhan pakcoy dibandingkan tumbuhan yang tidak diberikan pupuk organik. Dapat menjadi harapan bahwa hasil dari limbah cangkang telur dapat dimanfaatakan sebagaimana mestinya. Namun perlu dilakukan penelitian dan pengembangan kembali perihal potensi lainnya yang belum diketahui.

\section{UCAPAN TERIMAKASIH}

Ucapan terimakasih tersampaikan kepada Masyarakat Desa Kutamekar, Kecamatan Ciampel, Kabupaten Karawang yang telah memberikan izin untuk 
dilaksanakannya pengabdian kepada masyarakat.

\section{DAFTAR RUJUKAN}

Badan Pusat Statistik (BPS), 2016. Produksi Telur di Indonesia pada Tahun 2015, Jakarta: Badan Pusat Statistik Nasional.

Butcher, G. D. \& Miles, R., 2012. Concepts of Eggshell Quality. 1st ed. New York: Prentice Hall.

Ernawati, E. E., Noviyanti, A. R. \& Yuliyati, Y. B., 2019. Potensi Cangkang Telur sebagai Pupuk pada Tanaman Cabai di Desa Sayang Kabupaten Jatinangor. Jurnal Pengabdian Kepada Masyarakat, IV(5), pp. 123-125.

Mahreni, Sulistyowati, E., Sampe, S. \& Chandra, W., 2012. Pembuatan Hidroksi Apatit dari Kulit Telur. Yogyakarta, Prosiding Seminar Nasional Teknik Kimia.

Mushawwir, A. \& Latipudin, D., 2013. Biologi Sintesis Telur; Perspektif Fisiologis, Biokimia, dan Molekuler Produksi Telur. 1st ed. Yogyakarta: Graha IImu.

Noviyanti, A. R., Haryono, Pandu, R. \& Eddy, D. R., 2017. Cangkang Telur Ayam sebagai Sumber Kalsium dalam Pembuatan Hidroksiapatit untuk Aplikasi Graft Tulang. Chemica at Natura Acta, V(3), pp. 107-111.

Nurjayanti, Zulfita, D. \& Raharjo, D., 2012. Pemanfaatan Tepung Cangkang Telur sebagai Substitusi Kapur dan Kompos Kedelai terhadap Pertumbuhan dan Hasil Cabai Merah pada Tanah Aluvial. Jurnal Sains dan Mahasiswa Pertanian, I(3), pp. 16-21.

Nurlaela, A., Dewi, S. U. \& Soejoko, D. S., 2014. Pemanfaatan Limbah Cangkang Telur Ayam dan Telur Bebek sebagai Sumber Kalsium untuk Sintesis Mineral Tulang. Jurnal Pendidikan Fisika Indonesia, X(1), pp. 81-85.

Safitri, A. I., Muslihah, N. \& Winarsih, S., 2014. Kajian Penambahan Tepung Cangkang Telur Ayam Ras terhadap Kadar Kalsium, Viskositas, dan Mutu Organoleptik Susu Kedelai. Majalah Kesehatan FKUB, I(3), pp. 1-10.

Yonata, D., Aminah, S. \& Hersoelistyorini, W., 2017. Kadar Kalsium dan Karakteristik Fisik Tepung Cangkang Telur Unggas dengan Perendaman Berbagai Pelarut. Jurnal Pangan dan Gizi, VII(2), pp. 8293. 